\title{
Modified Biochar-A Tool for Wastewater Treatment
}

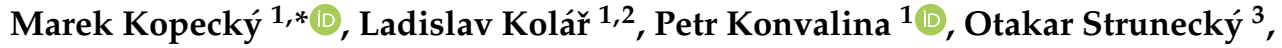 \\ Florina Teodorescu ${ }^{4}$, Petr Mráz $^{1}$, Jiří Peterka ${ }^{1}$, Radka Váchalová ${ }^{1}$, Jaroslav Bernas ${ }^{1}$, \\ Petr Bartoš ${ }^{1}\left(\mathbb{D}\right.$, Feodor Filipov ${ }^{5}$ and Daniel Bucur ${ }^{5}(\mathbb{D}$ \\ 1 Faculty of Agriculture, University of South Bohemia in Ceske Budejovice, Studentska 1668, \\ 37005 Ceske Budejovice, Czech Republic; kolar@zf.jcu.cz or 22152@mail.vstecb.cz (L.K.); \\ konvalina@zf.jcu.cz (P.K.); mrazpe01@zf.jcu.cz (P.M.); peterj03@zf.jcu.cz (J.P.); r.vachalova@seznam.cz (R.V.); \\ bernas@zf.jcu.cz (J.B.); bartos@zf.jcu.cz (P.B.) \\ 2 Faculty of Technology, Insitute of Technology and Business in Ceske Budejovice, Okruzni 10, \\ 37001 Ceske Budejovice, Czech Republic \\ 3 Faculty of Science, University of South Bohemia in Ceske Budejovice, Branisovska 1760, \\ 37005 Ceske Budejovice, Czech Republic; ostrunecky@prf.jcu.cz \\ 4 Costin D. Nenitescu Organic Chemistry Center of the Romanian Academy, Splaiul Independentei 202B, \\ RO-060023 Bucharest, Romania; ruxandra.teodorescu@nndkp.ro \\ 5 Department of Pedotechnics, Faculty of Agriculture, University of Agricultural Sciences and Veterinary \\ Medicine in Iasi, 3, Mihail Sadoveanu Alley, 700490 Iasi, Romania; ffilipov@uaiasi.ro (F.F.); \\ dbucur@uaiasi.ro (D.B.) \\ * Correspondence: mkopecky@zf.jcu.cz
}

Received: 7 September 2020; Accepted: 6 October 2020; Published: 11 October 2020

\begin{abstract}
Global deposits of concentrated phosphates, which are a necessary source for the production of phosphate fertilizers, are limited. These reserves keep getting thinner, and every day, large amounts of phosphorus end up in watercourses. In this study, we verified that modified biochar (saturated with $\mathrm{FeCl}_{3}$ solution and then neutralized with $\mathrm{NaOH}$ solution) can adsorb significant amounts of phosphorus from wastewater. Moreover, the agrochemical qualities of sludge water from a municipal wastewater treatment plant, struvite, phosphorus-saturated biochar, and iron(III) phosphate from a reused biochar filter were tested in this study. We determined the amount of mobile phosphorus as well as the amount of extractable phosphorus and its five fractions. It was found that modified biochar can hold one-third of the phosphorus amount contained in the commonly used agricultural fertilizer simple superphosphate $\left(1 \times 10^{5} \mathrm{~g}\right.$ of modified biochar captures up to $2.79 \times 10^{3} \mathrm{~g}$ of $\left.\mathrm{P}\right)$. Moreover, plants can more easily access phosphorus biochar fractions than struvite, which is formed spontaneously during sludge management. The results of this research prove that the proposed method of recycling phosphorus from wastewater can be applied in technological practice.
\end{abstract}

Keywords: biochar; fertilizer; iron(III) phosphate; phosphorus; purification; recycling; wastewater

\section{Introduction}

Phosphorus $(\mathrm{P})$ is the 11th most abundant element in the Earth's surface (reaching approximately $4 \times 10^{18} \mathrm{~g}$ of $\mathrm{P}$ ) and is, therefore, not considered to be geochemically rare [1]. However, the lack of highly concentrated phosphate reserves has been discussed [2] and, from a practical standpoint, can be considered non-renewable [3]. Phosphate deposits are also unevenly distributed worldwide [4]. For example, Morocco accounts for nearly $50 \%$ of natural P deposits [5].

About $90 \%$ of worldwide fossil phosphates are used for fertilizer production [6]. Mineral fertilizers are used in intensive farming systems worldwide. At the turn of the millennium, about $1 \times 10^{4} \mathrm{~g} \mathrm{P} \cdot \mathrm{ha}^{-1}$ was applied annually to agricultural land worldwide. In Europe, however, 
this value was $2.5 \times 10^{4} \mathrm{~g} \mathrm{P} \cdot \mathrm{ha}^{-1} \cdot$ year $^{-1}$ [7]. The total consumption of $\mathrm{P}$ fertilizers in the European Union (EU-27) is almost $1.4 \times 10^{6} \mathrm{~g} \cdot$ year $^{-1}$ [8].

Careless use of phosphorus fertilizers has led to eutrophication problems in developed and large developing countries [9]. A major problem responsible for agrochemicals (including P) escaping from fields is erosion [10]. This also is due to the fact that the efficiency of $P$ fertilizer uptake by plants ranges only from 10 to $25 \%$ [11]. Because of this, eutrophication is a global problem causing a decline in the quality of both fresh and marine water worldwide [12]. The continuing high levels of phosphorus leeching into water ecosystems will accelerate harmful processes such as algal blooms or hypoxia in aquatic ecosystems [13], which will lead to significant ecosystem changes and to endangerment of a significant number of species [14]. This is one of the most visible examples of biosphere changes due to human activities [15].

The problems caused by excess phosphorus in the wild are, therefore, unquestionable. On the other hand, phosphorus is a limited element for primary production in agricultural ecosystems [16], and the availability of $\mathrm{P}$ in agricultural soils is becoming a global problem [17]. Phosphorus is limited either because it is present in insufficient amounts in soils or in forms that are inaccessible to plants. These factors subsequently lead to a decrease in agricultural production [18].

The P cycle in the soil, and consequently other parts in the environment, is influenced not only by the intensity of sorption processes in the soil but also by the type and form of the phosphorus source, the climate, the microbial activity of the soil, and the plants themselves. Complex edaphic processes lead to $P$ immobilization in soil, hampering its timely and sufficient availability for uptake by plants [19]. P can also accumulate significantly in soil despite the current decline in its plant-accessible forms [20]. Therefore, balancing the complete soil system is the only reliable solution. This also takes into account, in addition to omnidirectional inputs and outputs, $\mathrm{P}$ transformations and cycles in the soil [21].

In the P cycle, including mining and processing, there are significant losses through its use and consumption. In the face of $P$ deficiency, it is a challenge to minimize these losses and use $P$ as efficiently as possible [22]. Estimates when reserves of $P$ fossil resources will be depleted vary. For example, Scholz and Wellmer [23] do not think this will happen in the coming decades. Cabeza et al. [24] predicted that global $P$ resources will be depleted in 70-175 years. Cordell and White [1] discussed in detail many aspects of $P$ reserves, mining, and consumption, and they explained why it is almost impossible to accurately predict the depletion of $\mathrm{P}$ reserves. However, there is general agreement that depletion will take place sooner or later.

While agriculture is the largest consumer of non-renewable phosphorus sources, it is not the only source of $\mathrm{P}$ ending up in water resources. For example, it is known that one person produces about 550 liters of urine per year [25], which contains about $365 \mathrm{~g}$ of $\mathrm{P}$ [26]. By converting this amount, we find that the wastewater of a city with 100,000 inhabitants contains $150 \mathrm{~m}^{3}$ of urine per day with $1 \times 10^{5} \mathrm{~g}$ of pure P. However, a number of products containing $P$ are used in households (for example, washing powders, toothpastes), which also reach the wastewater. Thus, on average, there is approximately $2.3 \mathrm{~g}$ of $\mathrm{P}$ for one person per day [27]. It is therefore clear that urban wastewater is a source of $\mathrm{P}$ that needs to be addressed.

Sludge water is an even richer source of $\mathrm{P}$. It is produced from wastewater during sludge management in urban wastewater treatment plants after anaerobic sludge stabilization. It often contains up to tens of $\mathrm{g} / \mathrm{L}$ of $\mathrm{P}$, although much lower concentrations are also common $\left(2.5-27.0 \mathrm{~g} \times 10^{-3} \mathrm{P} / \mathrm{L}\right)$ [28]. Sewage sludge is a seemingly accessible source of $\mathrm{P}$ for soil fertilization. However, there is risk of soil contamination; therefore, use of sludge is subject to strict legislation in developed countries. For this reason, farmers have limited interest in the use of sewage sludge for fertilization [29].

Due to the above-mentioned reasons (limited reserves of $P$ resources, eutrophication of water, etc.), it is necessary to recycle $\mathrm{P}$ as much as possible. Especially in developed countries, but also in developing countries, the issue of $P$ recovery from wastewater has been given considerable attention. 
A large number of technologies have already been developed for recycling $\mathrm{P}$, or at least removing it from wastewater. Only some of them are outlined below.

Currently, precipitation of struvite $\left(\mathrm{MgNH}_{4} \mathrm{PO}_{4} \cdot 6 \mathrm{H}_{2} \mathrm{O}\right)$ from sludge water after anaerobic sludge stabilization is considered the most promising method. Struvite is formed spontaneously at higher $\mathrm{pH}$ or in the presence of $\mathrm{Mg}^{2+}$ salts in sludge waters. With this technology, the struvite precipitation efficiency depends mainly on the Mg:NH4:P ratio and the $\mathrm{pH}$ of the sludge water. The molar ratio of $\mathrm{Mg}: \mathrm{P}$ should be 1.3:1 [30] with an optimum $\mathrm{pH}=9$, but a $\mathrm{pH}$ of 8.5 is sufficient [31]. Struvite is also known as a P fertilizer for soil [32,33]. It is a poorly soluble, crystalline substance that slowly releases both $\mathrm{P}$ and nitrogen into the soil [34]. However, further examination of whether P recycling technologies, crystallization precipitation technologies, etc., reduce $\mathrm{P}$ accessibility are needed.

Crystallization of $\mathrm{P}$ is another technology [35]. The process works well mainly at higher $\mathrm{P}$ concentrations in sludge water. It crystallizes calcium phosphate with crystallization cores, which are sand, slag, or diatomaceous earth particles in a fluidized bed reactor. The most promising crystallization technology is struvite crystallization.

The recovery of $\mathrm{P}$ is also possible using ion exchange. $\mathrm{PO}_{4}{ }^{3-}$ is removed from sludge water by porous P-selective media, exchanging with cations such as $\mathrm{Cl}^{-}$to produce P-depleted effluent while maintaining charge neutrality in the solid media [36].

Adsorption is another group of technologies. Sorbents with $\mathrm{Fe}, \mathrm{Ca}$, and $\mathrm{Al}$ are used whose interaction with $\mathrm{PO}_{4}{ }^{3-}$ leads to the formation of hydroxylapatite or vivianite minerals, to ion exchange by surface adsorption or internal ion exchange, or to the creation of hardly definable clusters. The sorbents used are fly ash, Fe oxides, blast furnace slag, and bauxite extraction wastes. Again, these technologies are suitable when there are higher concentrations of $P$ in sludge water and the plant-accessibility of $P$ in the product is low [37].

Phosphorus removal by magnetic microsorbents, such as carbonyl iron particles [38], or $\mathrm{Fe}_{3} \mathrm{O}_{4}$ nanoparticles embedded in an $\mathrm{SiO}_{2}$ matrix coated with P-selective $\mathrm{ZnFeZr} \mathrm{[39]} \mathrm{is} \mathrm{based} \mathrm{on} \mathrm{principles}$ similar to adsorption. Magnetic microsorbents are adsorbent materials that have magnetic properties when suspended in wastewater. Nutrients adsorbed on magnetic media are recovered by capturing the suspended media using high-gradient magnetic separators, with subsequent regeneration and precipitation from the regenerant [40].

Other methods used for wastewater treatment include, for example, artificial wetlands [41]. Another method is the biological removal of $\mathrm{P}$ using polyphosphate-accumulating bacteria [42]. This microbial process is called enhanced biological phosphorus removal and has, in practice, been incorporated into numerous activated sludge treatment plants [43]. Capturing $\mathrm{P}$ with biomass is also promising. Cyanobacteria (Phormidium bohneri, Rhodobacter capsulatus), algae (Chlorella vulgaris), or algae with macrophytes (Chlorella vulgaris and Lemna minuskula) are commonly used.

In the case of phosphorus in terrestrial ecosystems, the total phosphorus in soil is present in a large number of fractions. Most fractions contain $\mathrm{P}$ that is in a form not accessible to plants. Forms of $\mathrm{P}$ in the soil that have minimal importance in plant nutrition are usually iron phosphates, phosphorus from non-hydrolysable organophosphates, non-extractable (residual) phosphorus, and phosphorus from specific organophosphates (bound in humification products) [44].

Phosphorus from sewage sludge, sludge water, and other forms bound to an easily hydrolysable, and thus degradable, organic matter are easily accessible to plants [45]. Generally, mobile organic and inorganic phosphorus are critical for plants, especially phosphorus in soil solution, microbial biomass, mobile and potentially accessible organic phosphorus, and mobile and potentially accessible inorganic phosphorus. The mobile $\mathrm{P}$ fraction $\left(\mathrm{P}_{\mathrm{mob}}\right)$ encompasses $\mathrm{P}$ present in anions of water-soluble, inorganic salts and $\mathrm{P}$ present in easily mineralizable, organic forms. The extractable $\mathrm{P}$ fraction $\left(\mathrm{P}_{\text {extr }}\right)$ denotes the sum of calcium (Ca-P), aluminum (Al-P), and ferric (Fe-P) phosphates [46]. Ca-P can be divided into three categories: CaP-I, CaP-II, and CaP-III. Simply put, a higher Roman numeral indicates a reduced availability of $\mathrm{P}$ for plants. Al-P is even less accessible, and Fe-P shows an even worse degree of availability [47]. 
It is therefore clear from the text above that when considering the source of $\mathrm{P}$ as a plant nutrient, the amount of $\mathrm{P}$ in the product should be taken into account as well as its form and, hence, accessibility to plants. This research assumes the possibility of using modified biochar as a phosphorus sorbent in wastewater and, subsequently, as an easily accessible source of phosphorus for plants. The aim is to purify wastewater by removing phosphorus and, thus, reduce the amount that enters the environment as well as obtain a high-quality phosphorus fertilizer with high added value.

\section{Material and Methods}

\subsection{Origin and Characteristics of Products 1 and 2}

Product 1 was sludge water. Water was taken in September 2018 from the central wastewater treatment plant in Prague (Bubeneč, part of the city) after it passed through a sedimentation tank. Prior to sampling, phosphate precipitation was stopped. The sludge water had a temperature of $16{ }^{\circ} \mathrm{C}$ and $\mathrm{pH}$ 7.2. The concentration of $\mathrm{P}$ was $4.9 \times 10^{-2} \mathrm{~g} \mathrm{PO}_{4}{ }^{3-} / \mathrm{L}$, and total phosphorus was $6.2 \times 10^{-2} \mathrm{~g} \mathrm{P} / \mathrm{L}$.

Struvite (Product 2), which is generated spontaneously in the presence of $\mathrm{Mg}^{2+}$ in wastewater treatment plants, was also tested. Struvite precipitation from sludge water was carried out in a six-basin coagulation mixer for $24 \mathrm{~h}$ according to the methodology described by Sýkorová et al. [28]. Product 3, phosphorus-saturated biochar, and Product 4, iron(III) phosphate $\left(\left[\mathrm{Fe}\left(\mathrm{PO}_{4}\right)_{3}\right]^{6-}\right)$, are newly tested products whose technical development is described below.

\subsection{The Essence of the Technical Method to Obtain Products 3 and 4}

Recycling sorption technologies have been designed and tested. The sorbent was a biochar filter. Its sorption capacity was saturated with $\mathrm{FeCl}_{3}$ solution $(10 \%)$, neutralized with $\mathrm{NaOH}$ solution (5\%), and then washed with water.

After washing the saturated biochar filter with clean water, purified wastewater was pumped through the filter from the sewage treatment plant (the location of the biochar filter in the water purification process is shown in Figure 1). If P-rich sludge water from the treatment plant (after anaerobic sludge stabilization) is to be used, it must be cleared of suspended organic substances via sand filtration, and possibly also by activation, because the organic substances can quickly clog the biochar filter. After reaching the sorption capacity of the filter, it was then possible to select from two methods to use the obtained material.

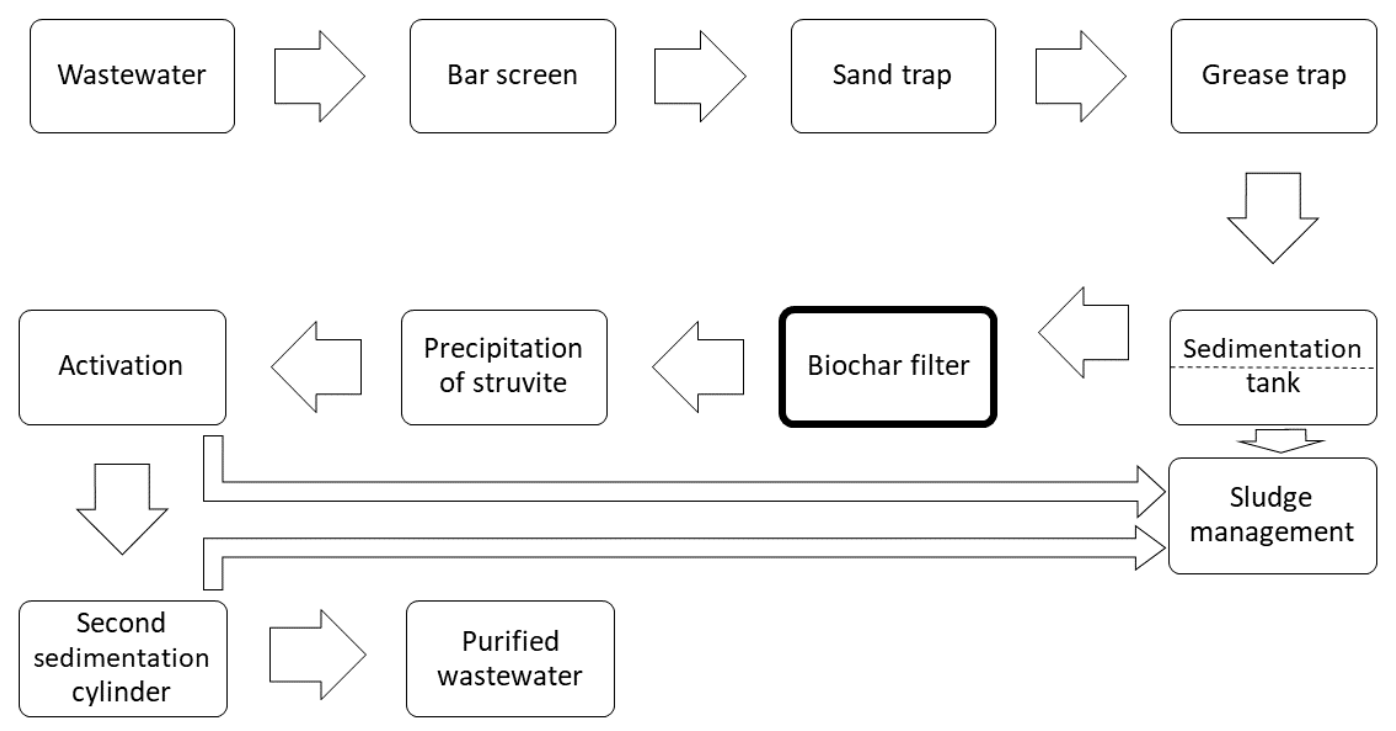

Figure 1. Wastewater management process. 
Phosphorus-saturated biochar, Product 3, was ready for use as a P fertilizer after drying.

If the other method is followed, in which the filter is used repeatedly, then Product 4 (iron(III) phosphate) is obtained. The filter was washed with dilute $\mathrm{HCl}(\mathrm{pH}$ of washing solution $=5.5)$. The solution was then neutralized with $\mathrm{NaOH}$ to $\mathrm{pH}=8$ to give iron(III) phosphate. The filter was again ready for use after re-saturation with iron.

\subsection{Description of the Practical Implementation of Products 3 and 4}

In the experiment, $200 \mathrm{~g}$ of biochar was used. The biochar was made from coconut shells via carbonization at a temperature of up to $350{ }^{\circ} \mathrm{C}$, then mixing with a $10 \% \mathrm{FeCl}_{3}$ solution, and finally leaving at $20^{\circ} \mathrm{C}$ for $12 \mathrm{~h}$. After filtration, a $5 \% \mathrm{NaOH}$ solution was allowed to flow through the wet biochar until the $\mathrm{pH}$ at the effluent remained unchanged. This was followed by washing with water until the $\mathrm{pH}$ at the effluent remained unchanged. Dry matter was found in the wet product after removing the water.

A phosphate solution was brought to the filter. Concentrations of $0,20,40,60,80$, and $100 \times 10^{-3} \mathrm{~g} \mathrm{P} / \mathrm{L}$ were used. The absorbed amount of $\mathrm{P}$ per $1 \mathrm{~g}$ of modified biochar and the equilibrium concentration of $\mathrm{P}$ in the solution after absorption were determined. A chart was then created in which the absorbed amount $\left(\mathrm{g} \cdot 10^{-3} \mathrm{P} / \mathrm{g}\right.$ of sorbent) was written on the vertical axis and the concentration of $\mathrm{P}(\mathrm{g} / \mathrm{L}$ of the equilibrium solution) on the horizontal axis. The chart showed how much $\mathrm{P}$ the biochar was able to capture. The empirical Freundlich isotherm for phosphorus adsorption was used:

$$
q=K_{f} \times c^{1 / n}
$$

where $q$ is the sorbed $\mathrm{P}$ ( $\mathrm{g} \cdot 10^{-3} \mathrm{P} / \mathrm{g}$ of sorbent), $K_{f}$ is the Freundlich partitioning coefficient, $c$ is the equilibrium $\mathrm{P}$ concentration in the supernatant solution $\left(\mathrm{g} \cdot 10^{-3} \mathrm{P} / \mathrm{L}\right)$, and $1 / n$ is the sorption intensity.

\subsection{Evaluation of Fertilizer Product Quality}

Consequently, the following fertilizers were used to evaluate the fertilizer efficiency:

1. Original sludge water,

2. Struvite precipitated from sludge water,

3. Phosphorus-saturated biochar, and

4. Iron(III) phosphate from a reused biochar filter.

Due to the low mobility of $\mathrm{P}$ in soil, long-term contact of the $\mathrm{P}$ source with soil was simulated to assess the agrochemical quality of the obtained fertilizer products.

A sample of Haplic Cambisol (Table 1) soil was saturated with water to maximum capillary capacity, released from the Kopecký cylinder, and crushed and combined with the investigated P source in a $1 \mathrm{~L}$ polyethylene bottle. To obtain measurable results, a higher total $\mathrm{P}$ addition was chosen (the same for all four phosphorous sources), namely $6.2 \times 10^{-3} \mathrm{~g}$ P per $1 \mathrm{~g}$ of soil. Thus, the sludge water had to be concentrated by evaporation in a water bath to one tenth of the volume. The bottle was sealed and shaken on a rotary shaker for $24 \mathrm{~h}$. Afterwards, it was stored in a thermostat at $28^{\circ} \mathrm{C}$ for 3 days. After removal from the thermostat, the bottle was emptied into a flat photographic dish, aerated, returned to the polyethylene bottle, and the evaporated water was added. This procedure was repeated 5 times.

Table 1. Phosphorus in Haplic Cambisol soil before the experiment ( \pm SD; Mehlich II).

\begin{tabular}{|c|c|c|c|c|c|c|c|c|}
\hline $\begin{array}{c}P_{\mathrm{mob}} \\
\left(\mathrm{g} \cdot 10^{-3}\right. \\
\left./ \mathrm{g} \cdot 10^{3}\right)\end{array}$ & $\begin{array}{c}P_{\text {extr }} \\
\left(\mathrm{g} \cdot \mathbf{1 0}^{-3}\right. \\
\left./ \mathrm{g} \cdot \mathbf{1 0}^{3}\right)\end{array}$ & $\begin{array}{c}\text { CaP I } \\
\left(\% P_{\text {extr }}\right)\end{array}$ & $\begin{array}{c}\text { CaP II } \\
\left(\% P_{\text {extr }}\right)\end{array}$ & $\begin{array}{l}\text { CaP III } \\
\left(\% P_{\text {extr }}\right)\end{array}$ & $\begin{array}{c}\text { AlP } \\
\left(\% P_{\text {extr }}\right)\end{array}$ & $\begin{array}{c}\text { FeP } \\
\left(\% P_{\text {extr }}\right)\end{array}$ & $\begin{array}{c}P_{\text {org }} \\
\left(\mathrm{g} \cdot 10^{-3}\right. \\
\left./ \mathrm{g} \cdot 10^{3}\right)\end{array}$ & $\begin{array}{c}P_{\text {tot }} \\
\left(\mathrm{g} \cdot 10^{-3}\right. \\
\left./ \mathrm{g} \cdot 10^{3}\right)\end{array}$ \\
\hline $25 \pm 4$ & $138 \pm 17$ & 10 & 14 & 22 & 26 & 28 & $294 \pm 23$ & $1828 \pm 22$ \\
\hline
\end{tabular}


Upon completion of preparing the experimental soil, the mobile phosphorus as well as extractable soil phosphorus and its five fractions (CaP-I, CaP-II, and CaP-III fractions, which are easily accessible to plants, and Al-P and Fe-P) were determined. Pmob was analyzed according Kovar and Piezinsky [48]. $\mathrm{P}_{\text {extr }}$ was analyzed according to Ginzburg and Lebedeva [49]. Following this procedure, $1 \mathrm{~g}$ of soil was extracted successively with $1 \%\left(\mathrm{NH}_{4}\right)_{2} \mathrm{SO}_{4}(\mathrm{pH} 4.8), 0.5 \mathrm{~N} \mathrm{CH}_{3} \mathrm{COOH}(\mathrm{pH} 4.2), 0.5 \mathrm{~N} \mathrm{NH}_{4} \mathrm{~F}(\mathrm{pH}$ 8.5), $0.1 \mathrm{~N} \mathrm{NaOH}$, and $0.5 \mathrm{~N} \mathrm{H}_{2} \mathrm{SO}_{4}$. Fractionation of organic $\mathrm{P}$ was not performed in this experiment.

Data were analyzed using STATISTICA (version 12, TIBCO Software Inc., Palo Alto, CA 94304 USA). One-way analysis of variance (ANOVA) with a subsequent post hoc Tukey test was used to analyze differences between P sources. The level of significance for all analyses was $\rho \leq 0.05$.

\section{Results and Discussion}

\subsection{Efficiency of Sorption}

This study of recycling phosphorus from wastewater using biochar brought attention-grabbing results. From Figure 2, it can be seen that the capacity of the modified biochar was $27.93 \mathrm{mg}$ of P . $\mathrm{g}^{-1}$ of sorbent. In other words, $1 \mathrm{~g}$ of given biochar (in the described treatment) at the maximum test concentration of the original solution $\left(100 \mathrm{~g} \times 10^{-3} \mathrm{P} / \mathrm{L}\right)$ was able to capture $27.93 \times 10^{-3} \mathrm{~g}$ of $\mathrm{P}$ (with a sorption efficiency of $27.9 \%$ ), i.e., $6.4 \times 10^{3} \mathrm{~g}$ of $\mathrm{P}_{2} \mathrm{O}_{5}$. For comparison, the classic, simple superphosphate $\mathrm{P}$ fertilizer contains about $16 \% \mathrm{P}_{2} \mathrm{O}_{5}$.

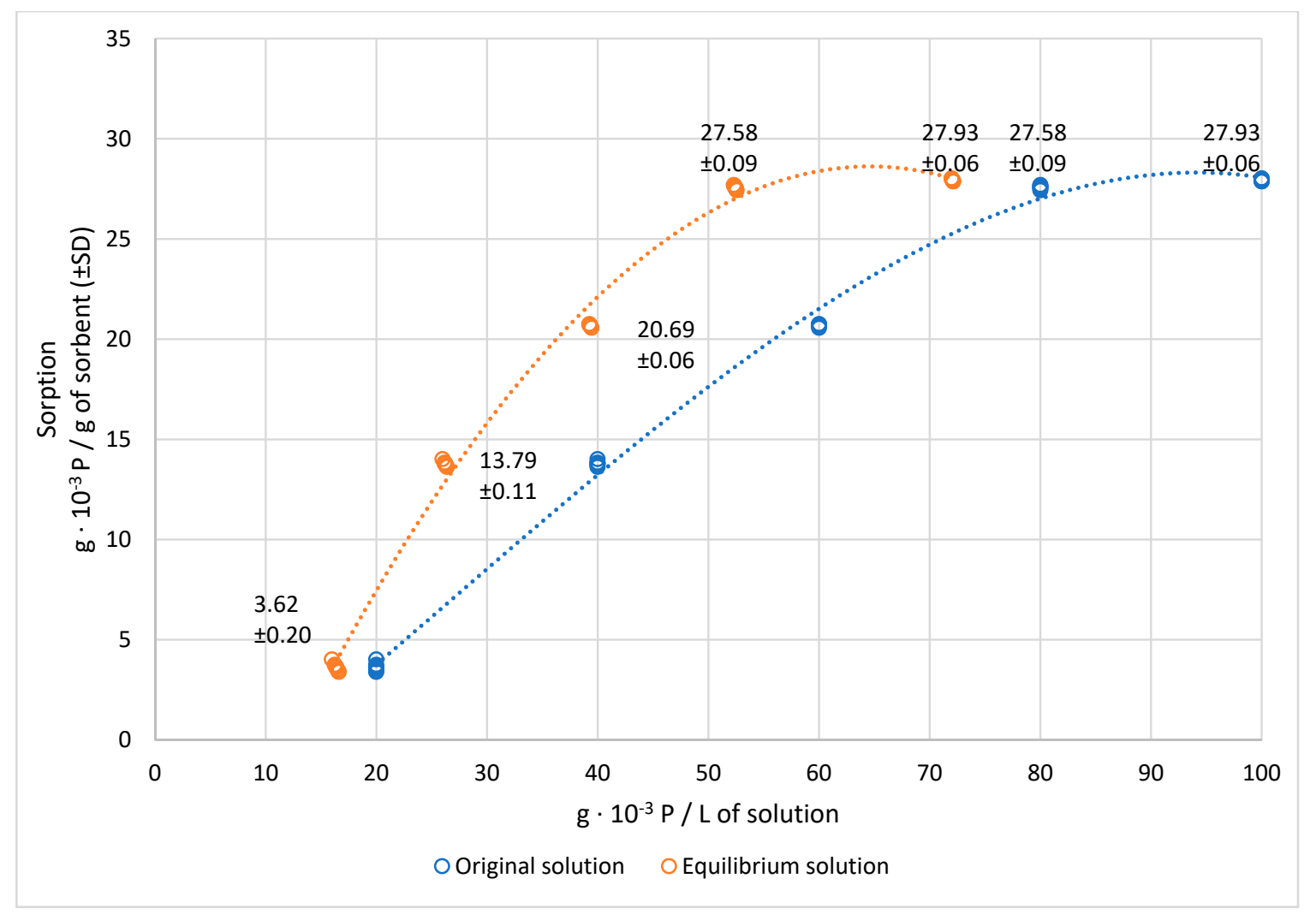

Figure 2. Adsorbed amount of phosphorus at different concentrations of solution.

However, a higher sorption efficiency was recorded in concentrations of $40-80 \mathrm{~g} \cdot 10^{-3} \mathrm{P} / \mathrm{L}$, and a maximum of $34.5 \% \mathrm{P}$ was purified from the wastewater. Nonetheless, the amount of adsorbed phosphorus was lower. If there was only $20 \times 10^{-3} \mathrm{~g} \mathrm{P} / \mathrm{L}$ in the wastewater, $1 \mathrm{~g}$ of biochar would only capture $3.6 \times 10^{-2} \mathrm{~g}$ of $\mathrm{P}$. The $\mathrm{P}$ content in the wastewater was reduced by less than one fifth (from $20 \times 10^{-3} \mathrm{~g} \mathrm{P} / \mathrm{L}$ to $16.4 \times 10^{-3} \mathrm{~g} \mathrm{P} / \mathrm{L}$ ). 
The Freundlich equation, which gives an expression that defines the surface heterogeneity and the exponential distribution of active sites and their energies, has the form $\mathrm{q}=8.625 \times \mathrm{c}^{1 / 0.735}$, where the coefficient of determination (R2) is 0.86 . In this context, it should be noted that the sorption properties of different biochars may be quite different depending on the type of pyrolysed organic matter or the temperature during the process [50].

Compared to technologies that employ struvite precipitation, sorption by a biochar filter appears to be less effective. The efficiency of $\mathrm{P}$ removal from wastewater by struvite precipitation is mentioned in the literature to be more than $90 \%$ [51]. For this reason, struvite precipitation should not be neglected in the wastewater treatment process, but instead placed behind the biochar filter.

\subsection{Quality of Products}

Four products were obtained from sludge management, which can be used as phosphorus fertilizers, and were analyzed. Differences in phosphorus content between various fractions (Figure 3 ) were found (one-way ANOVA, $\left.\mathrm{F}_{(9,34.223)}=34,153, p<0.0001\right)$.

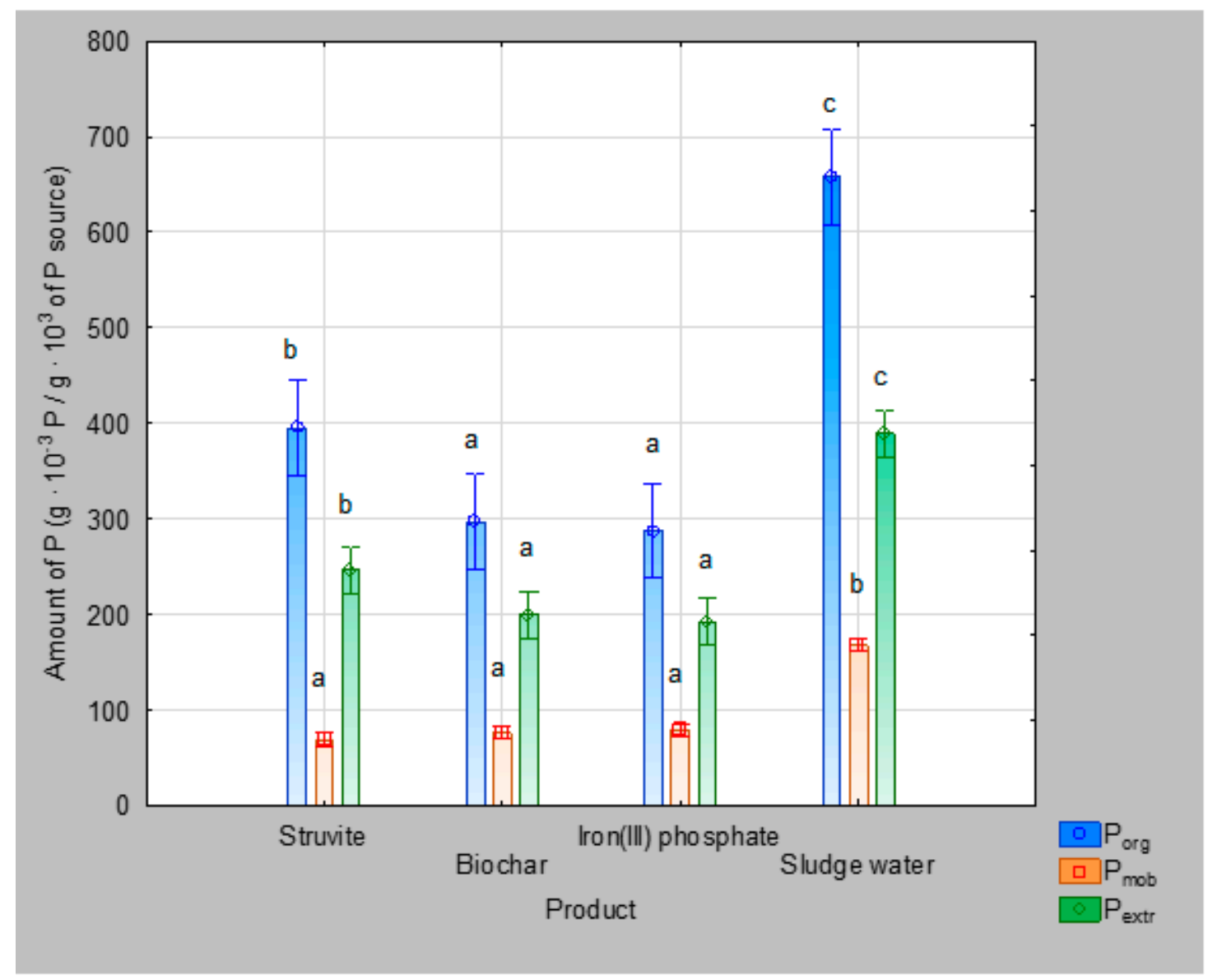

Figure 3. Phosphorus in Haplic Cambisol soil after addition of $6.2 \times 10^{-3} \mathrm{~g}$ of $\mathrm{P}$ (in phosphorus source)/g of soil (Mehlich II). Vertical bars denote 0.95 confidence intervals. Significant differences between the concentrations of different kinds of phosphorus among the tested extraction products are shown in small letters (Tukey's honest significance test).

The experiment proved that the original sludge water contained the highest amount of total phosphorus, including the $\mathrm{P}_{\text {mob }}$ fraction, which is crucial for plant nutrition. The $\mathrm{P}_{\text {org }}$ content was also the highest in sludge water, followed by struvite. In the biochar and iron (III) phosphate products, the amount of $\mathrm{P}_{\text {org }}$ was the lowest. The same order of values of phosphorus content was found in the $P_{\text {extr }}$ fraction. 
From the above, it seems that the application of sludge water to soil would be the most beneficial from a plant nutrition standpoint. However, the disadvantage of using sludge water is its high transport costs caused by the high water content [52]. Wider use of water sludge has also been hampered by strict legislative rules [53]. This is because sludge can contain harmful organic and inorganic contaminants, and in some cases the application of sludge to agricultural land can contaminate water, soil, and the food chain [54].

If we do not take into account wastewater, struvite contained the most $\mathrm{P}$ and may appear to be the best fertilizing product at first glance. It is also often rated as an excellent, slowly soluble $\mathrm{P}$ fertilizer in the literature $[32,55,56]$. However, from an agricultural point of view, the agrochemical quality of the obtained phosphorus sources is essential. Phosphorus is extremely immobile in soil [57], and its losses by washout from the soil are negligible. Moreover, the amount of $P$ in agricultural soils is still relatively small compared to what plants need in terrestrial agroecosystems [58]. The assumption that low solubility of $P$ fertilizers is an advantage for fertilization and plant nutrition is, therefore, not justified. As many accessible forms of phosphorus as possible are required in agricultural practice. The quality of struvite as a P fertilizer and its solubility were covered in Degryse et al. [59]. They assumed that struvite is considered by many authors to be a quality $\mathrm{P}$ fertilizer, as their results are based on experiments where struvite was mixed directly into soil in powder form. Nevertheless, in agricultural practice, struvite must be applied to fields in the form of granules. However, this form of struvite greatly reduces its solubility. Solubility is also significantly influenced by the soil $\mathrm{pH}$. Intensive biological activity also plays an important role in this context $[60,61]$. Thus, struvite as a phosphorus fertilizer is not optimal.

The distribution of $P_{\text {extr }}$ into fractions according to plant accessibility is shown in Figure 4. From the point of view of plant accessibility, the most important fractions were CaP-I and CaP-II. As far as these fractions are concerned, better results were found for products based on the use of biochar in comparison to struvite. Furthermore, both biochar-based products have fewer plant-inaccessible CaP-III fractions than struvite. If we compare phosphorus-saturated biochar and iron(III) phosphate from an agrochemical point of view, phosphorus-saturated biochar seemed to be slightly better. In addition, biochar itself has a number of properties that improve the soil $[62,63]$. The influence of biochar on the increase in soil water retention capacity [64] in support of biological activity [65] was described. Biochar is also important for climate protection because it can sequester carbon [66]. Compared to struvite, both biochar-based products have fewer plant-inaccessible CaP-III fractions.

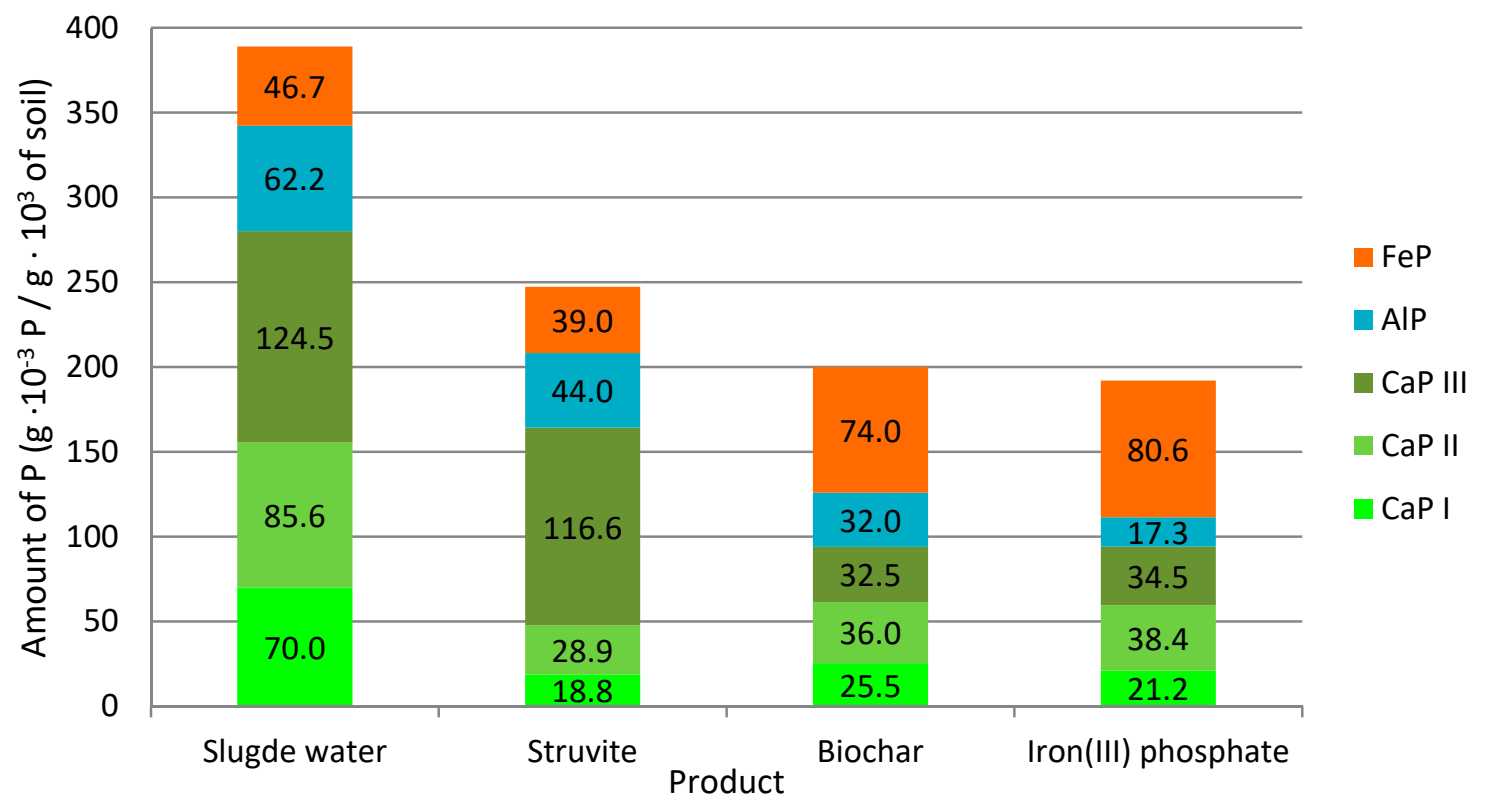

Figure 4. Fractionation of $P_{\text {extr }}$ into categories. 
The price of biochar is the main factor to consider, from an economic perspective, when implementing this technology. However, these costs can vary greatly over time, location, and input materials. Data on the price of biochar in specialized literature are different. According to Jirka and Tomlinson [67], the global mean price of $1 \times 10^{3} \mathrm{~g}$ of biochar is 2.65 USD. Vochozka et al. [68] report 0.3-0.5 EUR per $1 \times 10^{3} \mathrm{~g}$. Latawiec et al. [69] claim that the potential benefits of its use outweigh the great labor cost, and as a result biochar is $617 \%$ more expensive than common fertilizers. Nonetheless, biochar should not be valued via conventional nutrient optics (as fertilizer), nor as a biofuel. It should be priced, rather, for its soil-improving properties [70]. On the other hand, smaller-scale biochar production near feedstock sources and/or application sites that incorporate energy recovery can further reduce production costs, reaching close to zero. In addition, biochar cost could be further reduced when combined with other new technologies, for example novel thermosiphon-powered reverse osmosis [71] or solar thermal heating applications [72]. Therefore, its use and importance has increased in recent years [73]. Given the additional benefits from biochar use, such as carbon sequestration, farmers could also benefit from eventual payments for ecosystem services to leverage the costs and contribute to global goals to combat climate change [69].

\section{Conclusions}

The presumption that, from an agrochemical point of view, sludge water would be the best source of phosphorus for agricultural crops was confirmed (it contained the most phosphorus in all fractions). Nevertheless, its use in many countries is hindered by legal regulations. Therefore, other possibilities of using wastewater as a source of fertilizer for plants were investigated. We found that biochar can be successfully used in the wastewater treatment process as a phosphorus sorbent. Modified biochar in the amount of $1 \times 10^{5} \mathrm{~g}$ can capture $2.79 \times 10^{3} \mathrm{~g}$ of P. With this method of recycling, two types of products (phosphorous fertilizers) can be produced: iron(III) phosphate (possibility of repeated filter use) and phosphorus-saturated biochar. In addition to phosphorus, the latter product also supplies biochar to the soil, which is widely recognized to improve soil. Phosphorus-saturated biochar and iron(III) phosphate had good fertilizing properties; they contained a total of 61.5 and $59.6 \mathrm{~g} \times 10^{-3} \mathrm{P} / \mathrm{g} \cdot 10^{3}$ of soil, respectively, in easily accessible fractions CaP-I and CaP-II. Struvite, which is created spontaneously in wastewater treatment plants, contained only $47.7 \mathrm{~g} \times 10^{-3} \mathrm{P} / \mathrm{g} \cdot 10^{3}$ of soil in easily accessible fractions. It contained an especially low accessible CaP-III fraction (116.6 $\mathrm{g} \times 10^{-3} \mathrm{P} / \mathrm{g} \cdot 10^{3}$ of soil). Such fractions may be a source of P nutrients in the long-term, but they are unsuitable as an accessible fertilizer.

\section{Highlights}

- Retrieval of phosphorus from wastewater by a biochar filter

- Obtaining a soil improver containing easily plant-accessible phosphorus

- The technology has the potential for use in waste management and agriculture

Author Contributions: Conceptualization, M.K. and L.K.; methodology, L.K.; formal analysis, O.S.; investigation, F.T., J.P., R.V., J.B. and F.F.; resources, X.X.; data curation, O.S.; writing-original draft preparation, M.K. and L.K.; writing-review and editing, M.K and P.M.; supervision, D.B.; project administration, P.B.; funding acquisition, P.K. All authors have read and agreed to the published version of the manuscript.

Funding: This research was funded by the University of South Bohemia in Ceske Budejovice grant number GAJU 059/2019/Z.

Conflicts of Interest: The authors declare no conflict of interest.

\section{References}

1. Cordell, D.; White, S. Peak phosphorus: Clarifying the key issues of a vigorous debate about long-term phosphorus security. Sustainability 2011, 3, 2027. [CrossRef]

2. Reijnders, L. Phosphorus resources, their depletion and conservation-A review. Resour. Conserv. Recycl. 2014. [CrossRef] 
3. Zangarini, S.; Pepè Sciarria, T.; Tambone, F.; Adani, F. Phosphorus removal from livestock effluents: Recent technologies and new perspectives on low-cost strategies. Environ. Sci. Pollut. Res. 2020. [CrossRef]

4. El Wali, M.; Golroudbary, S.R.; Kraslawski, A. Impact of recycling improvement on the life cycle of phosphorus. Chin. J. Chem. Eng. 2019. [CrossRef]

5. Samreen, S.; Kausar, S. Phosphorus fertilizer: The Original and Commercial Sources. In Phosphorus-Recovery and Recycling; IntechOpen: London, UK, 2019. [CrossRef]

6. Gupta, D.K.; Chatterjee, S.; Datta, S.; Veer, V.; Walther, C. Role of phosphate fertilizers in heavy metal uptake and detoxification of toxic metals. Chemosphere 2014. [CrossRef] [PubMed]

7. Liu, Y.; Villalba, G.; Ayres, R.U.; Schroder, H. Global phosphorus flows and environmental impacts from a consumption perspective. J. Ind. Ecol. 2008. [CrossRef]

8. Van Dijk, K.C.; Lesschen, J.P.; Oenema, O. Phosphorus flows and balances of the European Union Member States. Sci. Total Environ. 2016. [CrossRef] [PubMed]

9. Yang, H.; Liu, Y.; Liu, J.; Meng, J.; Hu, X.; Tao, S. Improving the imbalanced global supply Chain of phosphorus fertilizers. Earth Futur. 2019. [CrossRef]

10. Chowdhury, R.B.; Chakraborty, P. Magnitude of anthropogenic phosphorus storage in the agricultural production and the waste management systems at the regional and country scales. Environ. Sci. Pollut. Res. 2016. [CrossRef]

11. Chien, S.H.; Prochnow, L.I.; Tu, S.; Snyder, C.S. Agronomic and environmental aspects of phosphate fertilizers varying in source and solubility: An update review. Nutr. Cycl. Agroecosyst. 2011. [CrossRef]

12. Le Moal, M.; Gascuel-Odoux, C.; Ménesguen, A.; Souchon, Y.; Étrillard, C.; Levain, A.; Moatar, F.; Pannard, A.; Souchu, P.; Lefebvre, A.; et al. Eutrophication: A new wine in an old bottle? Sci. Total Environ. 2019. [CrossRef] [PubMed]

13. Chowdhury, R.B.; Moore, G.A.; Weatherley, A.J.; Arora, M. Key sustainability challenges for the global phosphorus resource, their implications for global food security, and options for mitigation. J. Clean. Prod. 2017. [CrossRef]

14. Westphal, K.; Graeber, D.; Musolff, A.; Fang, Y.; Jawitz, J.W.; Borchardt, D. Multi-decadal trajectories of phosphorus loading, export, and instream retention along a catchment gradient. Sci. Total Environ. 2019. [CrossRef] [PubMed]

15. Li, M.; Wiedmann, T.; Hadjikakou, M. Towards meaningful consumption-based planetary boundary indicators: The phosphorus exceedance footprint. Glob. Environ. Chang. 2019. [CrossRef]

16. Schaller, J.; Faucherre, S.; Joss, H.; Obst, M.; Goeckede, M.; Planer-Friedrich, B.; Peiffer, S.; Gilfedder, B.; Elberling, B. Silicon increases the phosphorus availability of Arctic soils. Sci. Rep. 2019. [CrossRef]

17. Cordell, D.; Drangert, J.O.; White, S. The story of phosphorus: Global food security and food for thought. Glob. Environ. Chang. 2009. [CrossRef]

18. Zhu, J.; Li, M.; Whelan, M. Phosphorus activators contribute to legacy phosphorus availability in agricultural soils: A review. Sci. Total Environ. 2018. [CrossRef]

19. Bindraban, P.S.; Dimkpa, C.O.; Pandey, R. Exploring phosphorus fertilizers and fertilization strategies for improved human and environmental health. Biol. Fertil. Soils 2020. [CrossRef]

20. Menezes-Blackburn, D.; Giles, C.; Darch, T.; George, T.S.; Blackwell, M.; Stutter, M.; Shand, C.; Lumsdon, D.; Cooper, P.; Wendler, R.; et al. Opportunities for mobilizing recalcitrant phosphorus from agricultural soils: A review. Plant Soil 2018. [CrossRef]

21. Das, B.; Huth, N.; Probert, M.; Condron, L.; Schmidt, S. Soil phosphorus modeling for modern agriculture requires balance of science and practicality: A perspective. J. Environ. Qual. 2019. [CrossRef]

22. George, T.S.; Hinsinger, P.; Turner, B.L. Phosphorus in soils and plants-Facing phosphorus scarcity. Plant Soil 2016. [CrossRef]

23. Scholz, R.W.; Wellmer, F.W. Approaching a dynamic view on the availability of mineral resources: What we may learn from the case of phosphorus? Glob. Environ. Chang. 2013. [CrossRef]

24. Cabeza, R.; Steingrobe, B.; Römer, W.; Claassen, N. Effectiveness of recycled P products as P fertilizers, as evaluated in pot experiments. Nutr. Cycl. Agroecosyst. 2011. [CrossRef]

25. Senecal, J.; Vinnerås, B. Urea stabilisation and concentration for urine-diverting dry toilets: Urine dehydration in ash. Sci. Total Environ. 2017. [CrossRef] [PubMed] 
26. Vinnerås, B.; Palmquist, H.; Balmér, P.; Jönsson, H. The characteristics of household wastewater and biodegradable solid waste-A proposal for new Swedish design values. Urban Water J. 2006. [CrossRef]

27. Comber, S.; Gardner, M.; Georges, K.; Blackwood, D.; Gilmour, D. Domestic source of phosphorus to sewage treatment works. Environ. Technol. 2013. [CrossRef] [PubMed]

28. Sýkorová, E.; Wanner, J.̌̌.; Beneš, O.̌̌. Analysis of phosphorus recovery by struvite precipitation from sludge water in selected wastewater treatment plants. Chem. List. 2014, 108, 610-614.

29. Christodoulou, A.; Stamatelatou, K. Overview of legislation on sewage sludge management in developed countries worldwide. Water Sci. Technol. 2016. [CrossRef]

30. Kumari, S.; Jose, S.; Tyagi, M.; Jagadevan, S. A holistic and sustainable approach for recovery of phosphorus via struvite crystallization from synthetic distillery wastewater. J. Clean. Prod. 2020. [CrossRef]

31. Munch, E.V.; Barr, K. Controlled struvite crystallisation for removing phosphorus from anaerobic digester sidestreams. Water Res. 2001. [CrossRef]

32. Li, B.; Boiarkina, I.; Yu, W.; Huang, H.M.; Munir, T.; Wang, G.Q.; Young, B.R. Phosphorous recovery through struvite crystallization: Challenges for future design. Sci. Total Environ. 2019. [CrossRef] [PubMed]

33. Min, K.J.; Kim, D.; Lee, J.; Lee, K.; Park, K.Y. Characteristics of vegetable crop cultivation and nutrient releasing with struvite as a slow-release fertilizer. Environ. Sci. Pollut. Res. 2019. [CrossRef] [PubMed]

34. Capdevielle, A.; Sýkorová, E.; Biscans, B.; Béline, F.; Daumer, M.L. Optimization of struvite precipitation in synthetic biologically treated swine wastewater-Determination of the optimal process parameters. J. Hazard. Mater. 2013. [CrossRef] [PubMed]

35. Cornel, P.; Schaum, C. Phosphorus recovery from wastewater: Needs, technologies and costs. Water Sci. Technol. 2009. [CrossRef]

36. Perera, M.K.; Englehardt, J.D.; Dvorak, A.C. Technologies for recovering nutrients from wastewater: A critical review. Environ. Eng. Sci. 2019. [CrossRef]

37. Chrispim, M.C.; Scholz, M.; Nolasco, M.A. Phosphorus recovery from municipal wastewater treatment: Critical review of challenges and opportunities for developing countries. J. Environ. Manag. 2019. [CrossRef] [PubMed]

38. Merino-Martos, A.; de Vicente, J.; Cruz-Pizarro, L.; de Vicente, I. Setting up High Gradient Magnetic Separation for combating eutrophication of inland waters. J. Hazard. Mater. 2011. [CrossRef]

39. Drenkova-Tuhtan, A.; Schneider, M.; Meyer, C.; Franzreb, M.; Gellermann, C.; Mandel, K.; Steinmetz, H. Polishing of secondary wastewater effluents through elimination and recovery of dissolved phosphorus with reusable magnetic microsorbents. Proc. Water Environ. Fed. 2017. [CrossRef]

40. Mehta, C.M.; Khunjar, W.O.; Nguyen, V.; Tait, S.; Batstone, D.J. Technologies to recover nutrients from waste streams: A critical review. Crit. Rev. Environ. Sci. Technol. 2015. [CrossRef]

41. Wang, M.; Zhang, D.Q.; Dong, J.W.; Tan, S.K. Constructed wetlands for wastewater treatment in cold climate-A review. J. Environ. Sci. 2017, 57, 293-311. [CrossRef]

42. Henriet, O.; Meunier, C.; Henry, P.; Mahillon, J. Improving phosphorus removal in aerobic granular sludge processes through selective microbial management. Bioresour. Technol. 2016. [CrossRef]

43. Gonzalez-Gil, G.; Holliger, C. Dynamics of microbial community structure of and enhanced biological phosphorus removal by aerobic granules cultivated on propionate or acetate. Appl. Environ. Microbiol. 2011. [CrossRef] [PubMed]

44. Horáček, J.; Kolář, L.; Čechová, V.; Hřebečková, J. Phosphorus and carbon fraction concentrations in a cambisol soil as affected by tillage. Commun. Soil Sci. Plant Anal. 2008. [CrossRef]

45. Wollmann, I.; Gauro, A.; Müller, T.; Möller, K. Phosphorus bioavailability of sewage sludge-based recycled fertilizers. J. Plant Nutr. Soil Sci. 2018. [CrossRef]

46. Eriksson, A.K.; Gustafsson, J.P.; Hesterberg, D. Phosphorus speciation of clay fractions from long-term fertility experiments in Sweden. Geoderma 2015. [CrossRef]

47. Maroušek, J.; Stehel, V.; Vochozka, M.; Kolář, L.; Maroušková, A.; Strunecký, O.; Peterka, J.; Kopecký, M.; Shreedhar, S. Ferrous sludge from water clarification: Changes in waste management practices advisable. J. Clean. Prod. 2019. [CrossRef]

48. Kovar, J.L.; Pierzynski, G.M. Methods of Phosphorus Analysis for Soils, Sediments, Residuals, and Waters; Southern Cooperative Series Bulletin; North Carolina State University: Raleigh, NC, USA, 2009. 
49. Ginzburg, K.E.; Lebedeva, L.S. Method to determine mineral forms of soilphosphate. Agrochimija 1971, 1, 125-135. (In Russian)

50. Zhang, H.; Voroney, R.P.; Price, G.W. Effects of temperature and activation on biochar chemical properties and their impact on ammonium, nitrate, and phosphate sorption. J. Environ. Qual. 2017. [CrossRef]

51. Kataki, S.; West, H.; Clarke, M.; Baruah, D.C. Phosphorus recovery as struvite: Recent concerns for use of seed, alternative Mg source, nitrogen conservation and fertilizer potential. Resour. Conserv. Recycl. 2016. [CrossRef]

52. Qian, L.; Wang, S.; Xu, D.; Guo, Y.; Tang, X.; Wang, L. Treatment of municipal sewage sludge in supercritical water: A review. Water Res. 2016. [CrossRef]

53. Cieślik, B.M.; Świerczek, L.; Konieczka, P. Analytical and legislative challenges of sewage sludge processing and management. Mon. Chem. 2018. [CrossRef] [PubMed]

54. Seleiman, M.F.; Santanen, A.; Mäkelä, P.S.A. Recycling sludge on cropland as fertilizer-Advantages and risks. Resour. Conserv. Recycl. 2020. [CrossRef]

55. Hilt, K.; Harrison, J.; Bowers, K.; Stevens, R.; Bary, A.; Harrison, K. Agronomic Response of Crops Fertilized with Struvite Derived from Dairy Manure. Water Air Soil Pollut. 2016. [CrossRef]

56. Vaneeckhaute, C.; Janda, J.; Vanrolleghem, P.A.; Tack, F.M.G.; Meers, E. Phosphorus use efficiency of bio-based fertilizers: Bioavailability and fractionation. Pedosphere 2016. [CrossRef]

57. Van Paassen, J.G.; Britton, A.J.; Mitchell, R.J.; Street, L.E.; Johnson, D.; Coupar, A.; Woodin, S.J. Legacy effects of nitrogen and phosphorus additions on vegetation and carbon stocks of upland heaths. New Phytol. 2020. [CrossRef]

58. Cleveland, C.C.; Houlton, B.Z.; Smith, W.K.; Marklein, A.R.; Reed, S.C.; Parton, W.; Del Grosso, S.J.; Running, S.W. Patterns of new versus recycled primary production in the terrestrial biosphere. Proc. Natl. Acad. Sci. USA 2013. [CrossRef] [PubMed]

59. Degryse, F.; Baird, R.; da Silva, R.C.; McLaughlin, M.J. Dissolution rate and agronomic effectiveness of struvite fertilizers-Effect of soil $\mathrm{pH}$, granulation and base excess. Plant Soil 2017. [CrossRef]

60. Capdevielle, A.; Sýkorová, E.; Béline, F.; Daumer, M.L. Effects of organic matter on crystallization of struvite in biologically treated swine wastewater. Environ. Technol. 2016. [CrossRef]

61. Maroušek, J.; Kolář, L.; Strunecký, O.; Kopecký, M.; Bartoš, P.; Maroušková, A.; Cudlínová, E.; Konvalina, P.; Šoch, M.; Moudrý, J., Jr.; et al. Modified biochars present an economic challenge to phosphate management in wastewater treatment plants. J. Clean. Prod. 2020. [CrossRef]

62. Kamau, S.; Karanja, N.K.; Ayuke, F.O.; Lehmann, J. Short-term influence of biochar and fertilizer-biochar blends on soil nutrients, fauna and maize growth. Biol. Fertil. Soils 2019. [CrossRef]

63. Zhang, H.; Chen, C.; Gray, E.M.; Boyd, S.E.; Yang, H.; Zhang, D. Roles of biochar in improving phosphorus availability in soils: A phosphate adsorbent and a source of available phosphorus. Geoderma 2016. [CrossRef]

64. Wang, D.; Li, C.; Parikh, S.J.; Scow, K.M. Impact of biochar on water retention of two agricultural soils-A multi-scale analysis. Geoderma 2019. [CrossRef]

65. Lehmann, J.; Rillig, M.C.; Thies, J.; Masiello, C.A.; Hockaday, W.C.; Crowley, D. Biochar effects on soil biota-A review. Soil Biol. Biochem. 2011. [CrossRef]

66. Leng, L.; Huang, H.; Li, H.; Li, J.; Zhou, W. Biochar stability assessment methods: A review. Sci. Total Environ. 2019. [CrossRef] [PubMed]

67. Jirka, S.; Tomlinson, T. State of the Biochar Industry 2013-A Survey of Commercial Activity in the Biochar Field; International Biochar Initiative: Philadeplhia, PA, USA, 2014.

68. Vochozka, M.; Maroušková, A.; Váchal, J.; Straková, J. Biochar pricing hampers biochar farming. Clean Technol. Environ. Policy 2016. [CrossRef]

69. Latawiec, A.E.; Strassburg, B.B.N.; Junqueira, A.B.; Araujo, E.; Luiz, L.F.; Pinto, H.A.N.; Castro, A.; Rangel, M.; Malaguti, G.A.; Rodrigues, A.F.; et al. Biochar amendment improves degraded pasturelands in Brazil: Environmental and cost-benefit analysis. Sci. Rep. 2019. [CrossRef] [PubMed]

70. Maroušek, J.; Strunecký, O.; Stehel, V. Biochar farming: Defining economically perspective applications. Clean Technol. Environ. Policy 2019. [CrossRef]

71. Giwa, A.; Hasan, S.W. Novel thermosiphon-powered reverse osmosis: Techno-economic model for renewable energy and fresh water recovery. Desalination 2018. [CrossRef] 
72. Yacob, T.W.; Fisher, R.; Linden, K.G.; Weimer, A.W. Pyrolysis of human feces: Gas yield analysis and kinetic modeling. Waste Manag. 2018. [CrossRef]

73. Sri Shalini, S.; Palanivelu, K.; Ramachandran, A.; Raghavan, V. Biochar from biomass waste as a renewable carbon material for climate change mitigation in reducing greenhouse gas emissions-A review. Biomass Convers. Biorefinery 2020. [CrossRef] 